
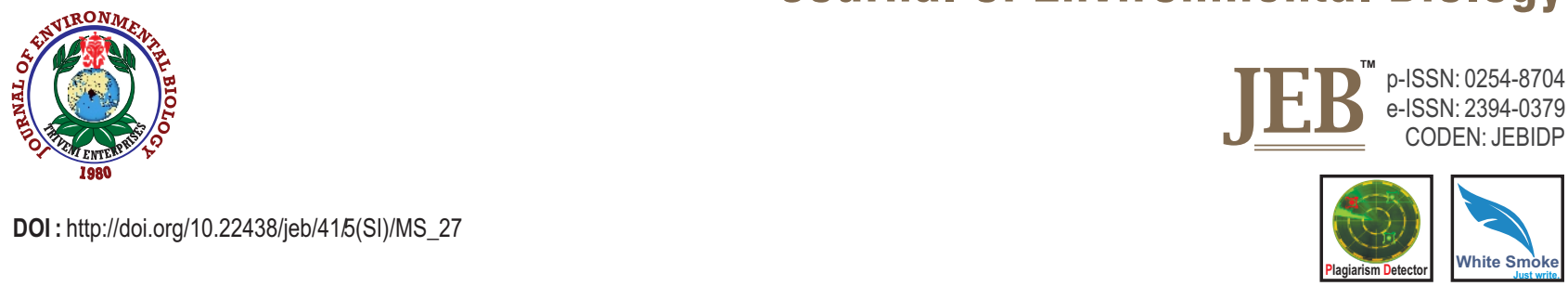

\title{
Reproductive biology of gray-eel catfish, Plotosus canius, in the coastal waters of Port Dickson, Peninsular Malaysia
}

\author{
B.I. Usman ${ }^{1,2}$, S.M.N. Amin ${ }^{1,3 *}$, A. Arshad ${ }^{1}$ and M.K. Abu Hena ${ }^{4}$ \\ ${ }^{1}$ Department of Aquaculture, Faculty of Agriculture Universiti Putra Malaysia, 43400, UPM Serdang, Selangor, Malaysia \\ ${ }^{2}$ Department of Fisheries and Aquaculture, Faculty of Agriculture, Bayero University, Kano-Nigeria \\ ${ }^{3}$ FAO World Fisheries University, Pukyong National University, Nam-gu, Busan 48547, South Korea \\ ${ }^{4}$ Faculty of Fisheries and Food Science, Universiti Malaysia Terengganu, 21030 Kuala Nerus, Terengganu, Malaysia \\ *Corresponding Author Email : smnabd@gmail.com
}

\section{Abstract}

Aim: The present work aimed at examining the reproductive biology of gray-eel catfish, Plotosus canius, from the coastal waters of Port Dickson, Peninsular Malaysia.

Methodology: Samples were collected on a monthly basis from fishermen during the full moon between January and December, 2012.

Results: The overall annual sex ratio was 1: 0.98 (males: females). The annual GSI variation indicated a long distinct breeding period from April to September; with major breeding activity between May and June. The length range of males at sexual maturity was $44-48 \mathrm{~cm}$ (mid length, $46 \mathrm{~cm}$ ) total length and that of the females was $40-44 \mathrm{~cm}$ (mid length, $42 \mathrm{~cm}$ ) total length. Fecundity of $P$. canius ranged from 643 to 1140 (mean $943 \pm 38.40$ ) eggs, and had a positive and significant relationship with body length, body weight and ovary weight. Females attained sexual maturity earlier than the males.

Interpretation: Knowledge on the reproductive biology of $P$. canius is useful for their conservation, successful culture and breeding programs.

Key words: Peninsular Malaysia, Plotosus canius, Port Dickson, Reproductive biology, Spawning season

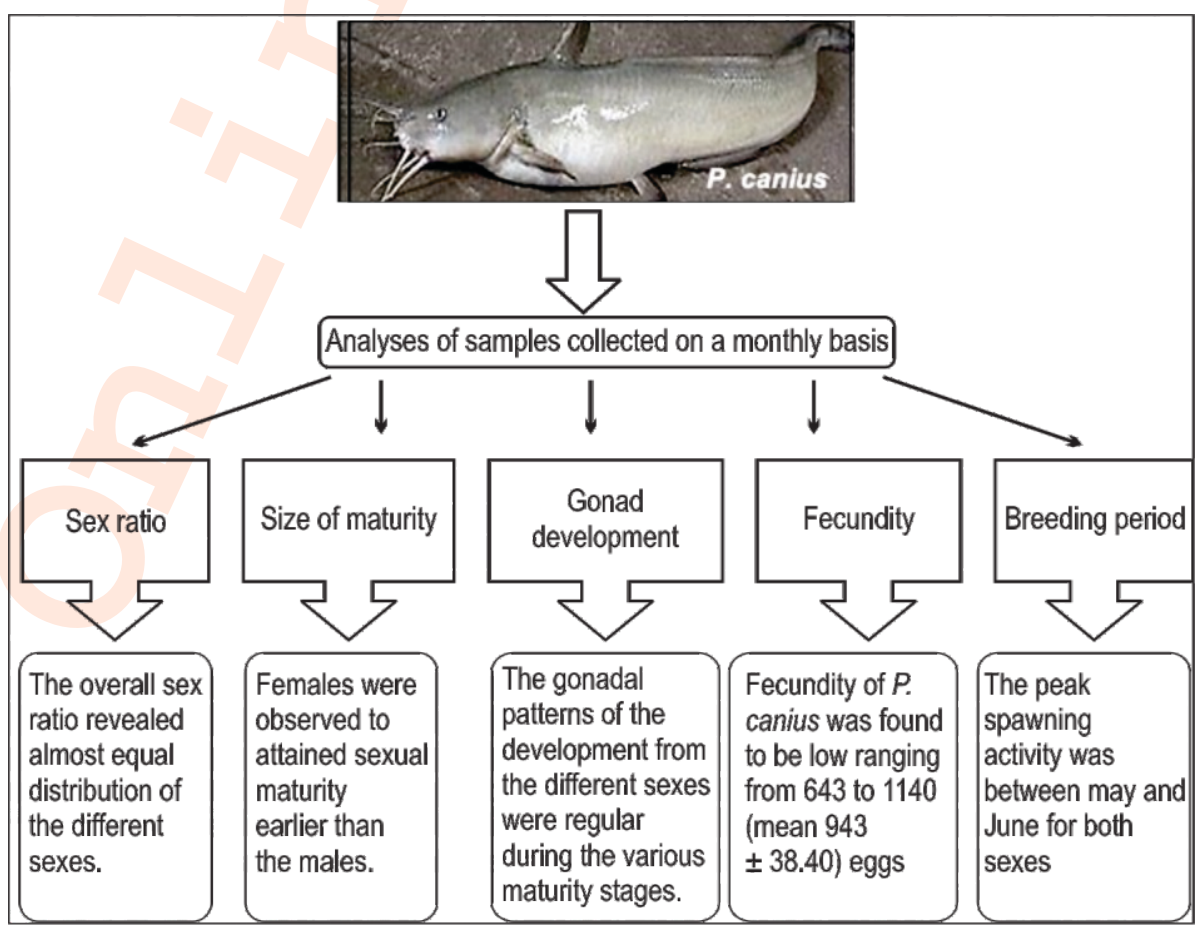

How to cite : Usman, B.I., S.M.N. Amin, A. Arshad and M.K. Abu Hena: Reproductive biology of gray-eel catfish, Plotosus canius, in the coastal waters of Port Dickson, Peninsular Malaysia. J. Environ. Biol., 41, 1339-1348 (2020). 


\section{Introduction}

The gray-eel catfish, Plotosus canius, is a native species throughout the Indo-Pacific region, including Australia, Bangladesh, India, Papua New Guinea, Srilanka, Philippines and Malaysia (Ferraris, 2007; Mohsin and Ambak, 1996). This commercially important species is often sold fresh in markets (Ambak et al., 2010; Gomon, 1984; Mohsin and Ambak, 1996). They serve as an important food source and income for many local communities (Nurnadia et al., 2011). While P. canius often live in coastal seas, they have also been reported to dwell in both brackish and fresh waters (Ambak et al., 2010; Mohsin and Ambak, 1996; Riede, 2004). Due to their popularity as a food fish, and ability to tolerate various water conditions, this fish has been cited as a potential aquaculture candidate (Khan et al., 2002). However, for the development of such an industry as well as implementation of effective fisheries resources management of any marine fish, there is a need to obtain basic information on their biology (Cross et al., 2014; Lawson, 2011; Mace, 1994; Muchlisin et al., 2010; Murawski et al., 2001). This can include knowledge of their reproductive biology such as sex ratio, gonadal development and maturity, spawning season, size at sexual maturity and fecundity. However, there is limited information on $P$. canius.

Information on the reproductive biology of $P$. canius has not been reported from Malaysia. The majority of studies have only been carried out in a small number of areas where the fish is distributed (Ahmed and Haque, 2007; Khan et al., 2002; Sinha, 1981; Sinha, 1984; Sinha, 1986a; Sinha, 1986b). Although the status of this fish has not been evaluated by the International Union for Conservation of Nature (IUCN) Red list (IUCN, 2017), it is one of thirty-nine other fish species that are facing extinction in India (Mijkherjee et al., 2002). In Bangladesh, P. canius is listed as a vulnerable fish species (IUCN Bangladesh, 2000). Consequently, their natural population has been declining, with very low catches from the fishing communities in the coastal waters of Malaysia. This may indicate that $P$. canius may become endangered in the near future. In general, the basic biology of $P$. canius is not well documented. No doubt, there is a clear need for more research on $P$. canius, which can be important in the management and conservation of this fish species. In view of the above, this study aimed at examining the reproductive biology of $P$. canius from the coastal waters of Port Dickson, Peninsular Malaysia.

\section{Materials and Methods}

Study site and sampling: The Kg Telok region of Port Dickson coastal waters is located off the straits of Malacca at $02^{\circ} 24.98^{\circ} \mathrm{N}$ latitude; $101^{\circ} 56.53^{\circ} \mathrm{E}$ longitude (Fig. 1). Twenty to thirty-two fish samples were collected on a monthly basis during full moon from fishermen. Sampling was done for a period of 12 months, between January and December, 2012 covering an annual cycle.

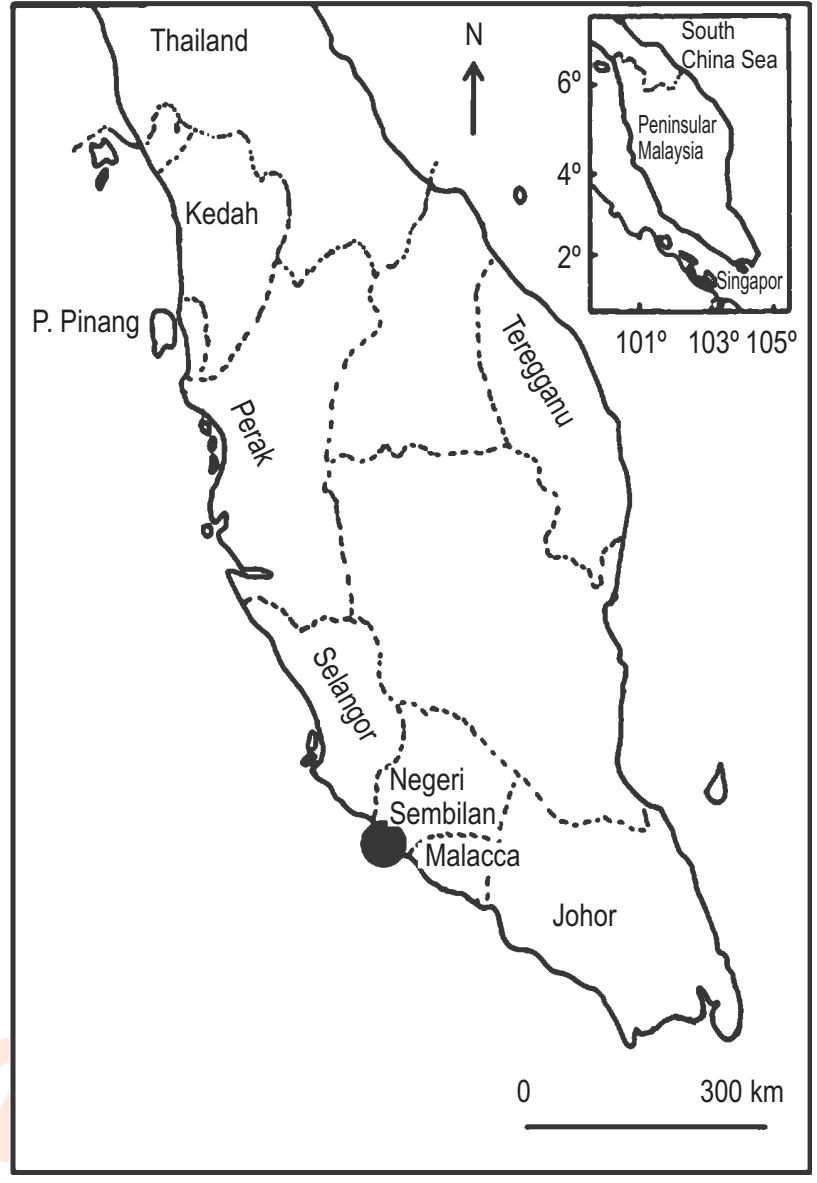

Fig. 1 : Geographical location of the sampling station (black dot) in the coastal waters of Port Dickson, Peninsular Malaysia.

The samples were immediately stored in ice and transported to the laboratory at Universiti Putra Malaysia for analysis.

Laboratory preparation: The fish were identified following the standard keys of Ambak et al. (2010), De Bruin et al. (1995); Mohsin and Ambak (1996). The total and standard lengths were measured to the nearest $0.1 \mathrm{~cm}$ using a measuring board, while the body weight was measured to the nearest $1.0 \mathrm{~g}$ using a top loading digital weighing balance (Simon TH-5000).

Sex ratio: Identifying sex solely based on external observations is not reliable in this species. Therefore, the fish were carefully dissected to obtain the gonads. The sex ratio (males: females) was estimated for different months and various size groups of the fish.

Gonad examination: The condition of the gonads from both males and females were examined every month. The fish were dissected, the gonads removed and then weighed to the nearest $0.01 \mathrm{~g}$ using electronic weighing balance (Setra EL-200S). The stages of gonadal maturity from both males and females were established within five categories based on their morphological 
appearance (macroscopic examination) using criteria by Muchlisin et al. (2010) with slight modifications. The gonadosomatic index (GSI) was calculated using an equation by Adebiyi etal. (2011).

$$
\text { Gonadosomatic index (GSI) }=\frac{\text { Gonad weight }(\mathrm{g})}{\text { Fish weight }(\mathrm{g})} \times 100
$$

The gonads were then preserved in $5 \%$ formalin for fecundity studies. The spawning season was ascertained based on the distribution of various maturity stages from males and females during different months and GSI.

Size at sexual maturity: The percentage of fish at each gonadal maturity stage was based on total length classes and was used for determining the size at first maturity and the length at which $50 \%\left(L_{50}\right)$ of the fish matured. The percentage of mature individuals (stages III-IV) was graphically plotted against length groups (Gomiero and Braga, 2004).

Fecundity and spawning pattern: Fecundity was estimated by examining the preserved ovaries from 40 gravid females (stages III and IV) by the formula given below (Gupta and Gupta, 2006):

$$
F=\frac{W(N 1+N 2+N 3)}{(W 1+W 2+W 3)}
$$

Where; F = Fecundity; $\mathrm{W}=$ Total weight of ovary; W1, W2 and W3 = weights of each sub-samples and N1, N2 and N3 = Egg counts in each sub-sample

Egg diameter was measured (in $\mathrm{mm}$ ) by randomly selecting the representatives of each preserved gonad developmental stage (stages III and IV). Samples of at least 250 eggs from the anterior, middle and posterior region of the ovary were randomly collected and measured for egg diameter using a KEYENCE (VHX-500) digital microscope.

The spawning patterns of the fish were evaluated based on the frequency of occurrence of various egg diameters in the mature ovaries. This was done by grouping the eggs into classes of different diameter sizes, depending on their frequency of occurrence to establish the type of spawning (Adebiyi et al., 2011; Araújo etal., 2012).

Statistical analysis: The sex ratio was tested for differences from the hypothetical ratio of 1:1 using a Chi-square test $\left(X^{2}\right)$. The data were subjected to a One-way ANOVA to examine the differences between means, and any differences were identified by using a least significant difference (LSD) test. A scatter plot was used to determine the relationship between fecundity and total length, body weight and ovarian weight. All statistical analyses were done using SPSS statistics software version 20 .

\section{Results and Discussion}

Size composition: A total of $341 P$. canius specimens were used for this investigation. For males, the minimum and maximum total lengths were $22.80 \mathrm{~cm}$ and $62.90 \mathrm{~cm}$, while for females the minimum and maximum total lengths were $24.60 \mathrm{~cm}$ and 60.00 $\mathrm{cm}$, respectively (Fig. 2). The average total length for males and females were $38.34 \mathrm{~cm}$ and $39.06 \mathrm{~cm}$, respectively, with no statistically significant difference. $(t=0.84 ; p=0.41)$. The body weight of males ranged from $66.0 \mathrm{~g}$ to $1188.0 \mathrm{~g}$, with a mean of $317.2 \mathrm{~g}$, while the body weight of females ranged from 77.0 $1028.0 \mathrm{~g}$, with a mean of $337.3 \mathrm{~g}$. Female $P$. canius were $20.1 \mathrm{~g}$ heavier than the males, no significant differences were detected $(\mathrm{t}$ $=0.90 ; p=0.340$ ). The relationship between body weight and total length of $P$. canius was linear and positive for both males and females, indicating that as the length increased, the weight also increased (Fig. 3a, b).

Sex ratio: The frequency occurrence of $P$. canius females $(n=$ $169)$ and males $(n=172)$ showed a sex ratio of $1: 0.98$ (males: females) with a slight predominance of males $(50.44 \%)$ in relation to females $(49.56 \%)$, which did not significantly deviate from the hypothetical ratio of 1: 1 (Chi-square test: $x^{2}=17.62, \mathrm{df}=11, \mathrm{p}=$ 0.91). There was a fluctuation in the monthly sex ratio, with more females during the months of January to April, August, October and December. Meanwhile, more males were observed during the months of May to July, September and November (Fig. 4). The proportion of males and females in relation to various sized groups is depicted in Fig. 5. There was a predominance of males in the lower sized groups ( $<40 \mathrm{~cm}$ total length); while from sizes $>$ 40 to $52 \mathrm{~cm}$, a predominance of females was observed. However, the difference between males and females among the various length groups was not significant $\left(x^{2}=9.31, p>0.05\right)$; except in 40 -44 and $56-60 \mathrm{~cm}\left(x^{2}=12.26, p<0.001 ; x^{2}=15.88, p<0.001\right)$. No females were observed to be larger than $60 \mathrm{~cm}$.

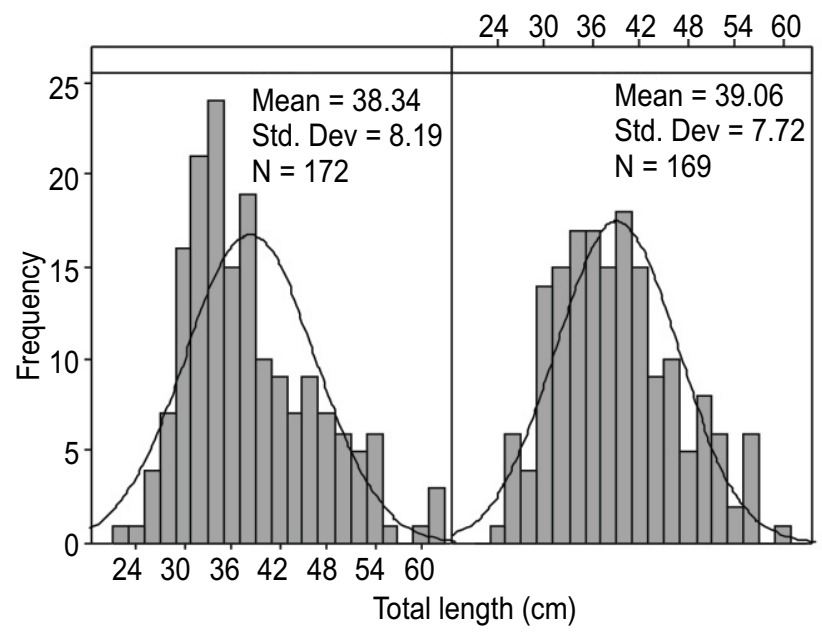

Fig. 2 : Annual size frequency distributions of male and female $P$. canius from the coastal waters of Port Dickson from January to December, 2012. 

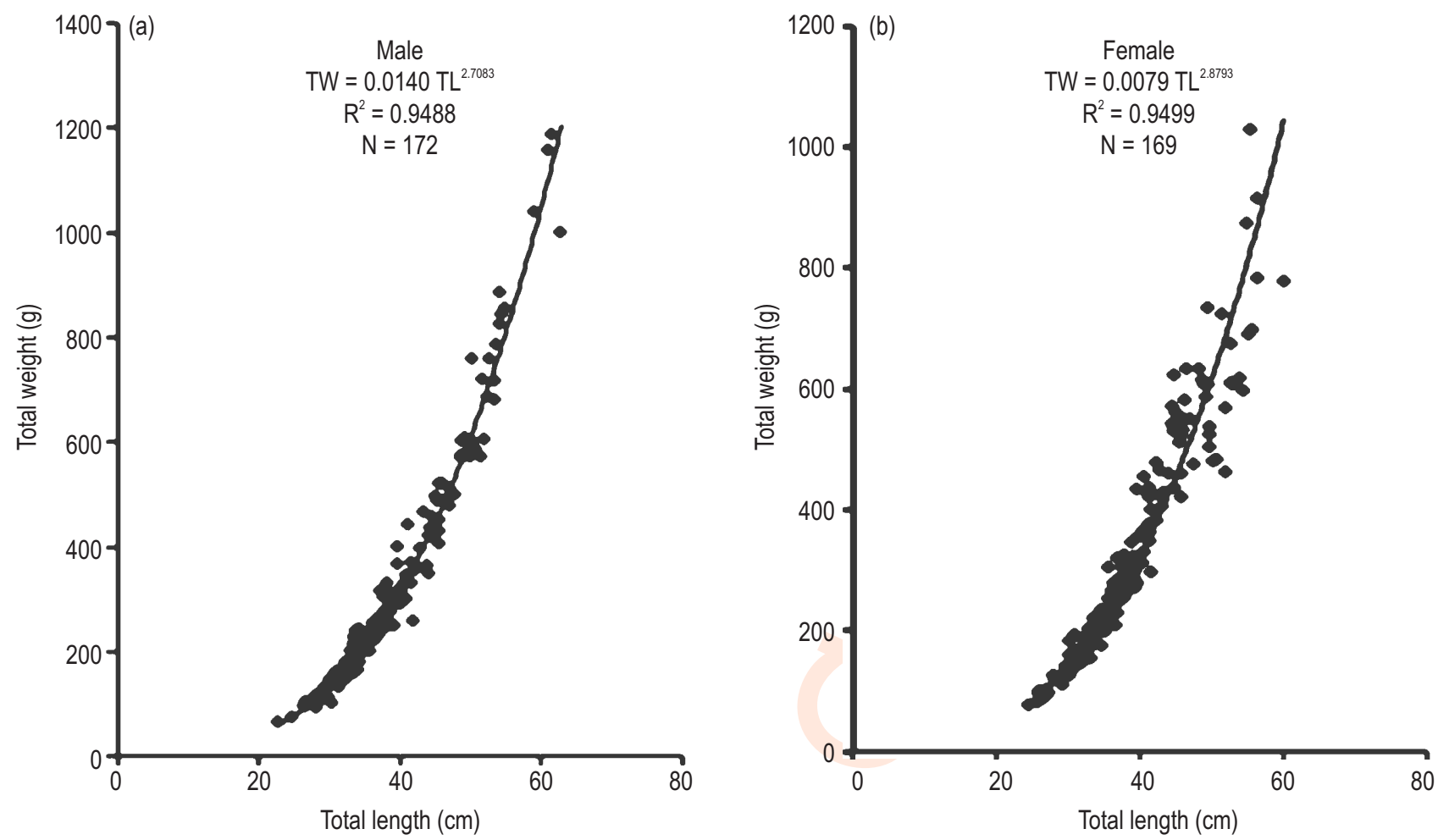

Fig. 3 : (a) Adjusted curve of empirical points of total length and body weight of male P. canius; (b) adjusted curve of empirical points of total length and body weight of female $P$. canius.

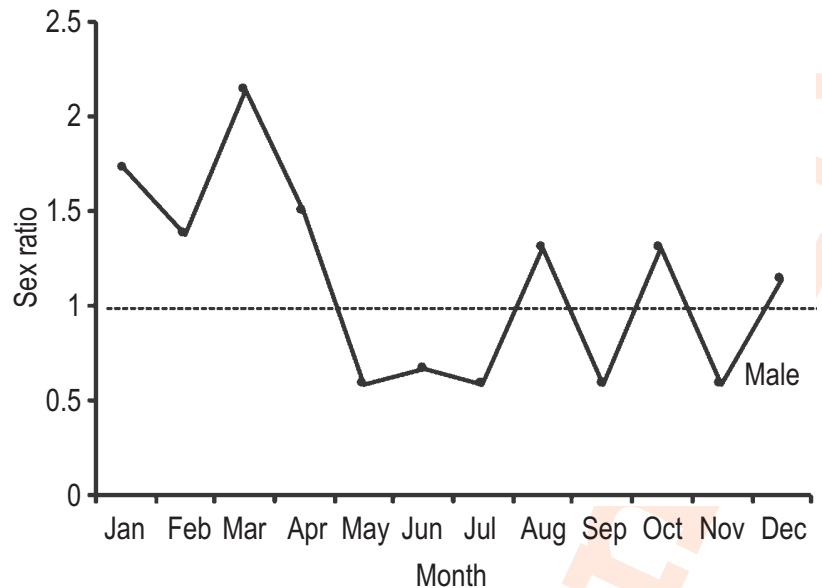

Fig. 4 : Monthly variations in sex ratio of $P$. canius in the coastal waters of PortDickson, Peninsular Malaysia.

Gonad maturation: The gonads in both males (testes) and females (ovaries) were paired bi-lobed in shape, elongated, symmetrical and were joined at the posterior region which produced a short duct leading to the urinogenital opening. The gonads were also situated in the posterior-dorsal sections of the coelomic cavity and ran ventral to the swim bladder and kidneys. The macroscopic appearance of various stages of gonad maturity for both males and females are presented in Table 1. Five different stages were identified; stage I (immature), stage II (maturing),

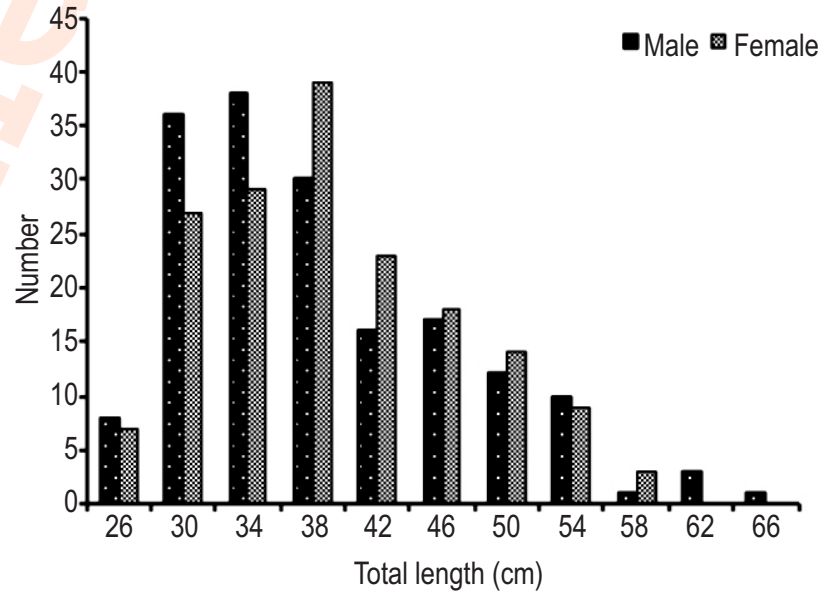

Fig. 5 : Variation in sex ratio of different size groups of $P$. canius in the coastal waters of Port Dickson, Peninsular Malaysia.

stage III (mature); stage IV (ripe) and stage V (spent). The gonads between stages III and IV were considered sexually matured. A higher proportion of sexually matured individuals (both males and females) were observed in February, March and April. Meanwhile, the highest proportions of spent gonads were found in May for both males and females and June for the females (Fig. 6 and 7).

Spawning season and type of spawning: The seasonal cycle of the GSI for both males and females showed many fluctuations 
Table 1 : Descriptions of male and female gonad developmental stages of $P$. canius in the coastal waters of Port Dickson, Peninsular Malaysia

\begin{tabular}{|c|c|c|c|c|c|c|}
\hline \multirow[t]{2}{*}{ Stages } & \multirow[t]{2}{*}{ Classification } & \multicolumn{2}{|c|}{ Macroscopic appearance } & \multirow{2}{*}{$\begin{array}{l}\text { Oocyte size } \\
(\mathrm{mm})\end{array}$} & \multicolumn{2}{|l|}{ GSI (\%) } \\
\hline & & Testes & Ovary & & $\mathbf{F}$ & M \\
\hline I & Immature & $\begin{array}{l}\text { Testes were very thin, thread- } \\
\text { like, whitish and translucent. } \\
\text { They occupied a small part of } \\
\text { the body cavity and was in } \\
\text { closeproximity to the vertebral } \\
\text { column }\end{array}$ & $\begin{array}{l}\text { Ovaries were very small, } \\
\text { flat, translucent and colourless. } \\
\text { They occupied a very small } \\
\text { part of the body cavity with no } \\
\text { prominent blood vessels. } \\
\text { Had very small oocytes, } \\
\text { which may be discernible to } \\
\text { the naked eye. }\end{array}$ & $\begin{array}{l}0.42-1.93 \\
(0.94 \pm 0.25)^{e}\end{array}$ & $\begin{array}{l}0.02-1.12 \\
(0.82 \pm 0.18)^{\mathrm{e}}\end{array}$ & $\begin{array}{l}0.01-0.09 \\
(0.05 \pm 0.01)^{\mathrm{e}}\end{array}$ \\
\hline$\|$ & Maturing & $\begin{array}{l}\text { Longer testes, about } 1 / 2 \text { the } \\
\text { length of the body cavity. } \\
\text { Whitish in colour and convoluted } \\
\text { with rough edges. }\end{array}$ & $\begin{array}{l}\text { Larger ovaries, pale-orange } \\
\text { colour. Ovary slightly less than } \\
\text { half of the length of the body } \\
\text { cavity. Few blood vessels may } \\
\text { be prominent. Oocytes very } \\
\text { small and may be discernible } \\
\text { to the naked eye. }\end{array}$ & $\begin{array}{l}1.99-4.37 \\
(3.12 \pm 0.45)^{c}\end{array}$ & $\begin{array}{l}0.21-8.67 \\
(4.97 \pm 2.33)^{\circ}\end{array}$ & $\begin{array}{l}0.03-0.17 \\
(0.08 \pm 0.03)^{c}\end{array}$ \\
\hline III & Mature & $\begin{array}{l}\text { Testes were larger, more } \\
\text { convoluted and leaf-like in } \\
\text { appearance. Occupied about } \\
3 / 4 \text { the length of the body cavity, } \\
\text { orange red in colour and } \\
\text { translucent. }\end{array}$ & $\begin{array}{l}\text { Ovaries large and orange-red } \\
\text { in colour. Occupied more than } \\
3 / 4 \text { th length of the body cavity. } \\
\text { Abdomen was slightly bulged } \\
\text { and blood vessels were prominent. } \\
\text { Oocytes were opaque, yolked and } \\
\text { larger in size. }\end{array}$ & $\begin{array}{l}3.55-6.10 \\
(4.41 \pm 0.58)^{b}\end{array}$ & $\begin{array}{l}4.76-22.08 \\
(13.32 \pm 5.13)^{b}\end{array}$ & $\begin{array}{l}0.04-0.20 \\
(0.10 \pm 0.06)^{b}\end{array}$ \\
\hline IV & Ripe & $\begin{array}{l}\text { General appearance same as } \\
\text { III, but occupied the entire } \\
\text { length of the body cavity and } \\
\text { were creamy in colour. }\end{array}$ & $\begin{array}{l}\text { Very large ovaries that } \\
\text { extended over the entire length } \\
\text { and volume of the body cavity, } \\
\text { with the abdomen fully bulging. } \\
\text { Blood vessels were more } \\
\text { prominent covering the ovaries.. } \\
\text { Large oocytes were yellowish in } \\
\text { colour with a central yolk mass and } \\
\text { were easily extruded when slight } \\
\text { pressure was applied to the } \\
\text { abdomen. }\end{array}$ & $\begin{array}{l}3.58-6.90 \\
(5.34 \pm 0.13)^{\mathrm{a}}\end{array}$ & $\begin{array}{l}7.23-27.13 \\
(20.62 \pm 8.36)^{a}\end{array}$ & $\begin{array}{l}0.05-0.26 \\
(0.13 \pm 0.08)^{a}\end{array}$ \\
\hline V & Spent & $\begin{array}{l}\text { Testes appeared much reduced } \\
\text { in size and thinner. They were } \\
\text { deflated and translucent with } \\
\text { a blood shot appearance or } \\
\text { pale red in colour. }\end{array}$ & $\begin{array}{l}\text { Shrunken ovaries and became } \\
\text { flaccid, like an empty deflated } \\
\text { sac, red-brown or bloody in } \\
\text { appearance. No prominent blood } \\
\text { vessels. Oocytes were smaller. }\end{array}$ & $\begin{array}{l}0.45-2.43 \\
(1.09 \pm 0.01)^{d}\end{array}$ & $\begin{array}{l}1.27-2.79 \\
(1.57 \pm 0.67)^{d}\end{array}$ & $\begin{array}{l}0.02-0.14 \\
(0.06 \pm 0.02)^{d}\end{array}$ \\
\hline
\end{tabular}

M-male; F-female; values in parenthesis are means \pm SD; values in the same column followed by a different superscript are significantly different $(p<0.05)$.

and are shown in Fig. 8. Female GSI was significantly higher than that of males (t-test, $p<0.001$ ). The GSI of males ranged from 0.04 to $0.074 \%$, with a maximum index during February to April (0.061 to $0.074 \%)$ and minimum during September $(0.041 \%)$. In case of females, the GSI ranged from 0.163 to $11.965 \%$ and the maximum GSI value was also obtained during February to April $(8.977$ to $11.965 \%)$ with a minimum in September $(0.163 \%)$. The GSI for both sexes began to increase from October, which continued to gradually increase until January. From February, the GSI rapidly increased that reached a peak in April; thereafter this sharply declined in May and reached a resting level in September
(Fig. 8). The highest peak for female GSI was observed in April, which was significantly different from the other months $(p<0.05)$. Meanwhile for male GSI, this also peaked in April and was significantly different from other months except March $(p>0.05)$.

Fig. 9 shows a plot of GSI and the egg size of different gonadal developmental stages of female $P$. canius. There was a general increase in GSI from immature stage (I) to ripe stage (IV) and then decreased in the spent stage (V). Egg size also increased from stage I (immature stage) to stage IV (ripe stage), and thereafter decreased abruptly as the fish was spent (stage V). 


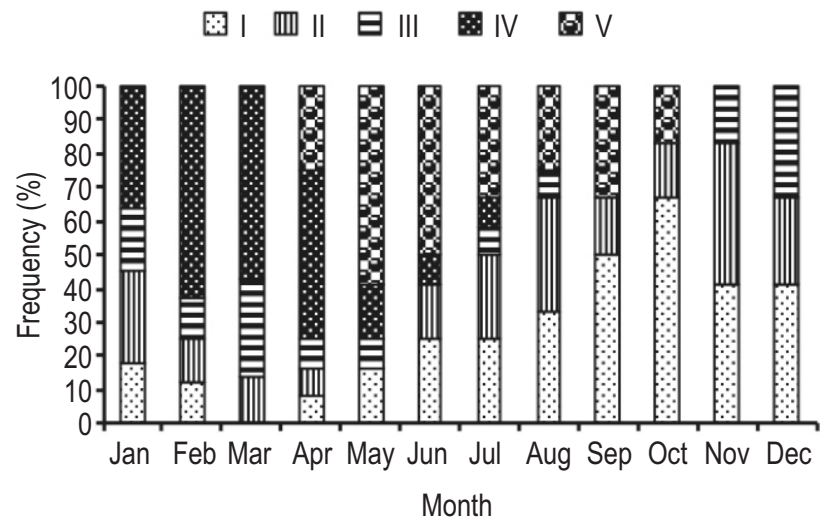

Fig. 6 : Monthly changes in the percentage of occurrence of gonad stage of males P. canius.

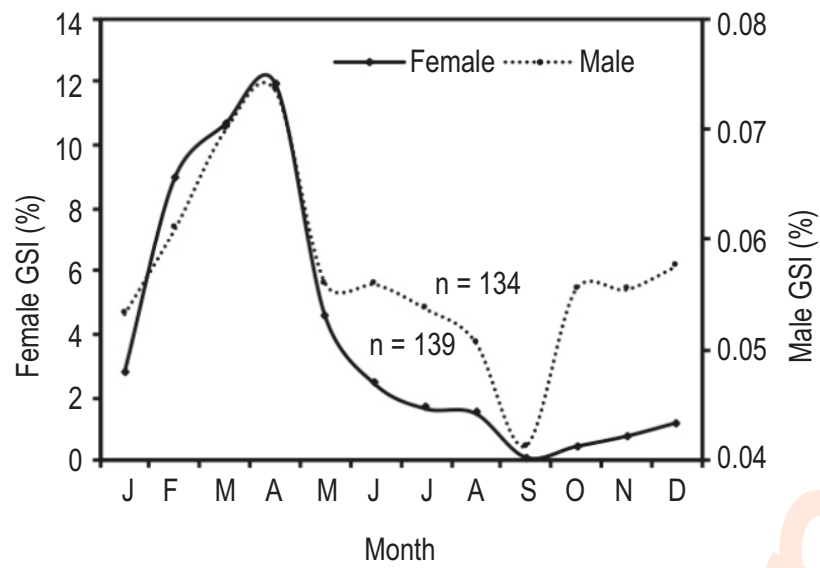

Fig. 8 : Monthly variations in the gonadosomatic index (GSI) of both male and female $P$. canius in the coastal waters of Port Dickson, Peninsular Malaysia.

The egg diameter frequency distribution of female $P$. canius (Fig. 10) followed a single bell curve.

Size at sexual maturity: To establish the size at which the fish reached sexual maturity, a total of 172 males and 169 females were used. The smallest males and females that had matured gonads (stages III and above) in the samples were regarded as the size at first sexual maturity. The percentage occurrence of matured males and females were plotted against various sized groups in males and females (Fig. 11). It was found that the smallest size, at which maturity was found in males and females, were between size groups $32-36 \mathrm{~cm}$ total length (mid length, 34 $\mathrm{cm}$ ) and $36-40 \mathrm{~cm}$ (mid length, $38 \mathrm{~cm}$ ), respectively. It also revealed that $50 \%$ of males became mature at the size group 44 $48 \mathrm{~cm}$ total length (mid length, $46 \mathrm{~cm}$ ), while $50 \%$ of females were matured at the size group $40-44 \mathrm{~cm}$ total length (mid length, 42 $\mathrm{cm}$ ). All males matured at size $56-60 \mathrm{~cm}$ onwards; whereas all females matured at size $48-52 \mathrm{~cm}$ onwards.

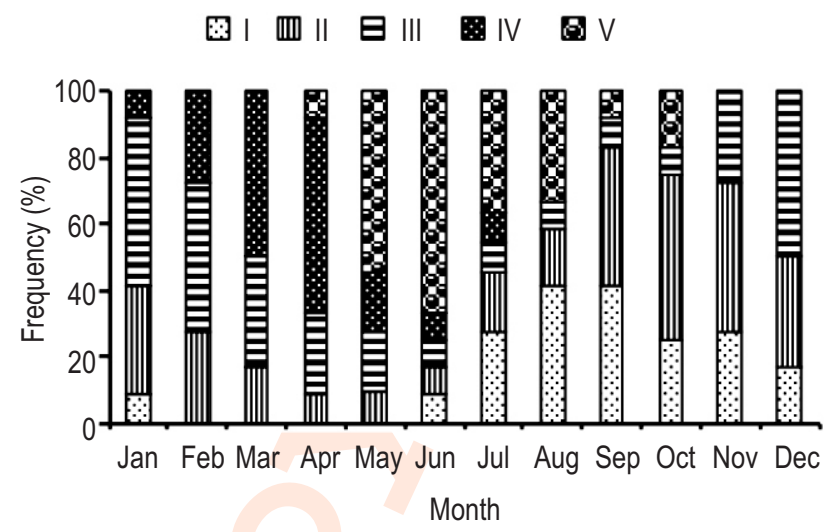

Fig. 7 : Monthly changes in the percentage of occurrence of gonad stage of females $P$. canius.

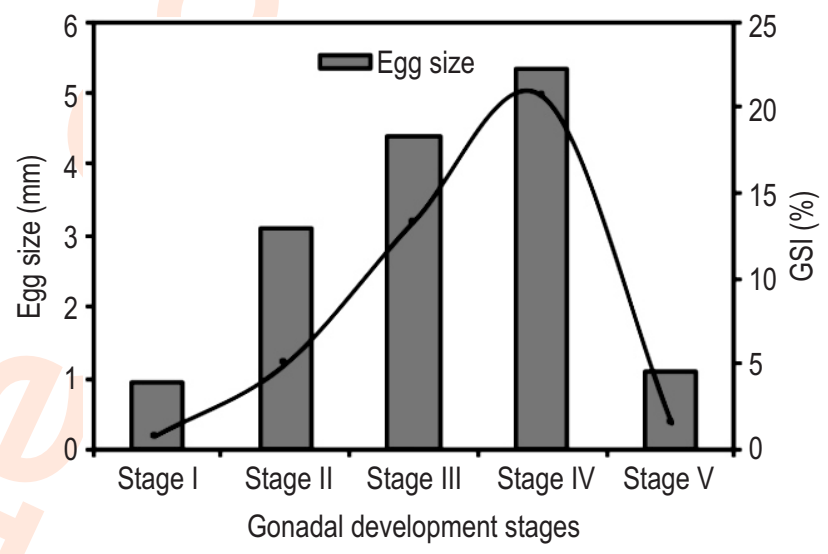

Fig. 9 : A plot of GSI and egg size against the various gonadal development stages of females $P$. canius.

Fecundity: The number of ova from females with mature ovaries was counted from 40 females and the estimated number of eggs from different sized groups is depicted in Table 2. The results showed that fecundity varied from 642 to 1140 eggs in individuals of 40 to $60 \mathrm{~cm}$. The mean fecundity value of 40 females was 943.05 eggs. The average number of eggs per $1 \mathrm{~kg}$ body weight of the fish was calculated to be 1225.89 eggs. Models of linear and exponential regression were used to analyze the relationship between fecundity ( $F$ ) and total length ( $T L$ ), body weight (BW) and ovary weight (OW). The relationship between fecundity and total length, fecundity and body weight as well as fecundity and ovary weight is presented in Fig. 12. The relationships are expressed by the following equations:

$Y=0.298+1.575 X\left(R^{2}=0.8662, N=40, p<0.05\right)$, where $Y=$ fecundity and $X=$ total length $(\mathrm{cm})$.

$Y=0.811+0.750 X\left(R^{2}=0.8556, N=40, p<0.05\right)$, where $Y=$ fecundity and $X=$ body weight $(\mathrm{g})$. 
Table 2 : Fecundity of $P$. canius at various length groups

\begin{tabular}{lcccccc}
\hline $\begin{array}{l}\text { TL range } \\
(\mathbf{c m})\end{array}$ & $\begin{array}{c}\text { Mean length } \\
(\mathbf{c m})\end{array}$ & $\begin{array}{c}\text { Body weight } \\
(\mathbf{g})\end{array}$ & $\begin{array}{c}\text { Ovary weight } \\
(\mathbf{g})\end{array}$ & Total no of eggs & $\begin{array}{l}\text { No of eggs/ } \\
\text { g ovary weight }\end{array}$ & $\begin{array}{l}\text { No of eggs/ kg } \\
\text { body weight }\end{array}$ \\
\hline $40-42$ & $41.02 \pm 0.43$ & $472.40 \pm 61.63$ & $49.85 \pm 5.73$ & $642.26 \pm 24.53$ & 12.88 & 1359.57 \\
$42-44$ & $43.13 \pm 0.65$ & $575.00 \pm 68.50$ & $61.90 \pm 25.58$ & $704.99 \pm 80.19$ & 11.39 & 1226.07 \\
$44-46$ & $45.05 \pm 0.49$ & $640.90 \pm 57.78$ & $143.48 \pm 64.58$ & $832.04 \pm 41.01$ & 5.80 & 1298.24 \\
$46-48$ & $46.73 \pm 1.01$ & $743.00 \pm 92.80$ & $259.97 \pm 14.02$ & $916.37 \pm 92.92$ & 3.52 & 1233.34 \\
$48-50$ & $49.13 \pm 0.50$ & $793.00 \pm 63.55$ & $263.04 \pm 13.42$ & $954.10 \pm 22.29$ & 3.63 & 1203.15 \\
$50-52$ & $51.45 \pm 0.44$ & $930.00 \pm 29.71$ & $350.24 \pm 18.92$ & $1045.04 \pm 20.97$ & 2.98 & 1123.70 \\
$52-54$ & $52.83 \pm 0.60$ & $887.33 \pm 38.55$ & $334.45 \pm 19.11$ & $1031.17 \pm 42.36$ & 3.08 & 1162.10 \\
$54-56$ & $55.25 \pm 0.07$ & $968.50 \pm 24.75$ & $392.61 \pm 11.24$ & $1065.52 \pm 25.67$ & 2.71 & 1100.18 \\
$56-58$ & $56.67 \pm 0.38$ & $840.33 \pm 31.90$ & $385.78 \pm 35.30$ & $1098.69 \pm 1.20$ & 2.85 & 1307.45 \\
$58-60$ & $58.87 \pm 0.47$ & $842.33 \pm 6.11$ & $404.79 \pm 6.54$ & $1140.34 \pm 32.91$ & 2.82 & 1353.79 \\
Average & $50.01 \pm 0.50$ & $769.28 \pm 47.53$ & $264.61 \pm 31.44$ & $943.05 \pm 38.40$ & 5.17 & 1225.89 \\
\hline
\end{tabular}

Values are means $\pm S D ; T L-$ Total length.

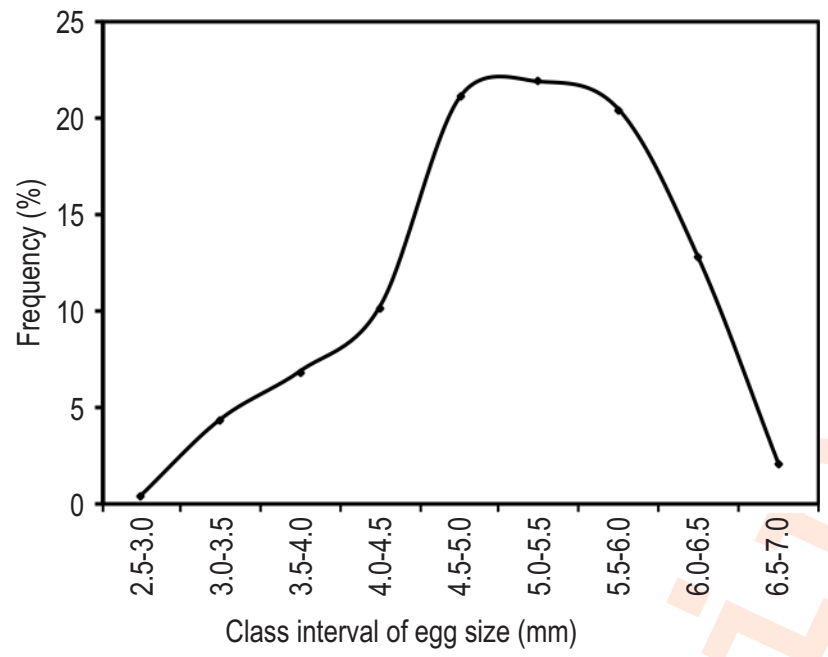

Fig. 10 : Frequency of egg occurrence from different class intervals of mature female $P$. canius.

$Y=2.416+0.237 X\left(R^{2}=0.9527, N=40, p<0.05\right)$, where $Y=$ fecundity and $X=$ ovary weight $(\mathrm{g})$.

From the scattered plots of the relationships between fecundity and total length, fecundity and body weight, as well as fecundity and ovary weight, a linear and positive relationship existed between fecundity and each of these three variables.

The sex ratio of $P$. canius showed fluctuations in the distribution between each sex, however the overall sex ratio was 1: 0.98 (males: females), thus revealing an equal distribution of different sexes. In nature, the sex ratio is expected to be around 1 : 1 , and any divergence from this ratio signifies the dominance of one sex over the other. Previous studies have not investigated the sex ratio of $P$. canius, therefore comparisons with other studies

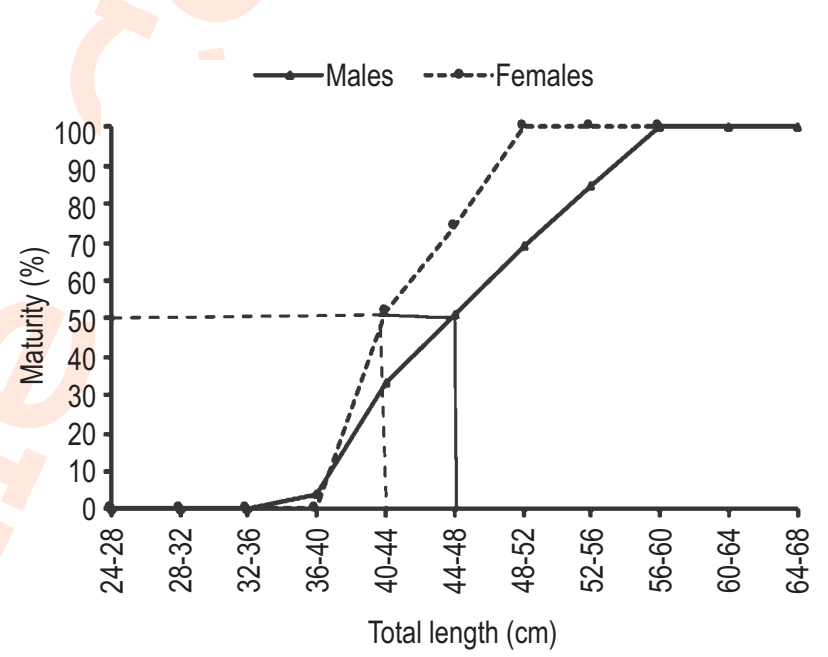

Fig. 11 : Length at maturity of $P$. canius in the coastal waters of Port Dickson, Malaysia.

cannot be done. Nevertheless, this is in agreement with Araújo et al. (2012) who also observed slight predominance of males over females in Crenicichla menezesi; although not significant. Kamrani et al. (2010) observed predominance of males over females in the blue swimmer crab, Portunus pelagicus. However, the predominance of females was reported in catfish, Liposarcus multiradiatus (Liang et al., 2005), Pseudocorynopoma doriai (Ferriz et al., 2007), Acetes indicus (Amin et al., 2009), Liza abu (Chelemal et al., 2009), Rasbora tawarensis (Muchlisin et al., 2010), Mystus tengara (Gupta and Banerjee, 2013). The sex ratio can also differ from one population of the same species to another, and may also vary year to year (Gupta and Gupta, 2006; Wang et al., 2003). Variation in sex ratio can also occur as a result of fishing gear (Wang et al., 2003), differences in mortality and behavioural characteristics (Kim, 2005), species, condition of the 

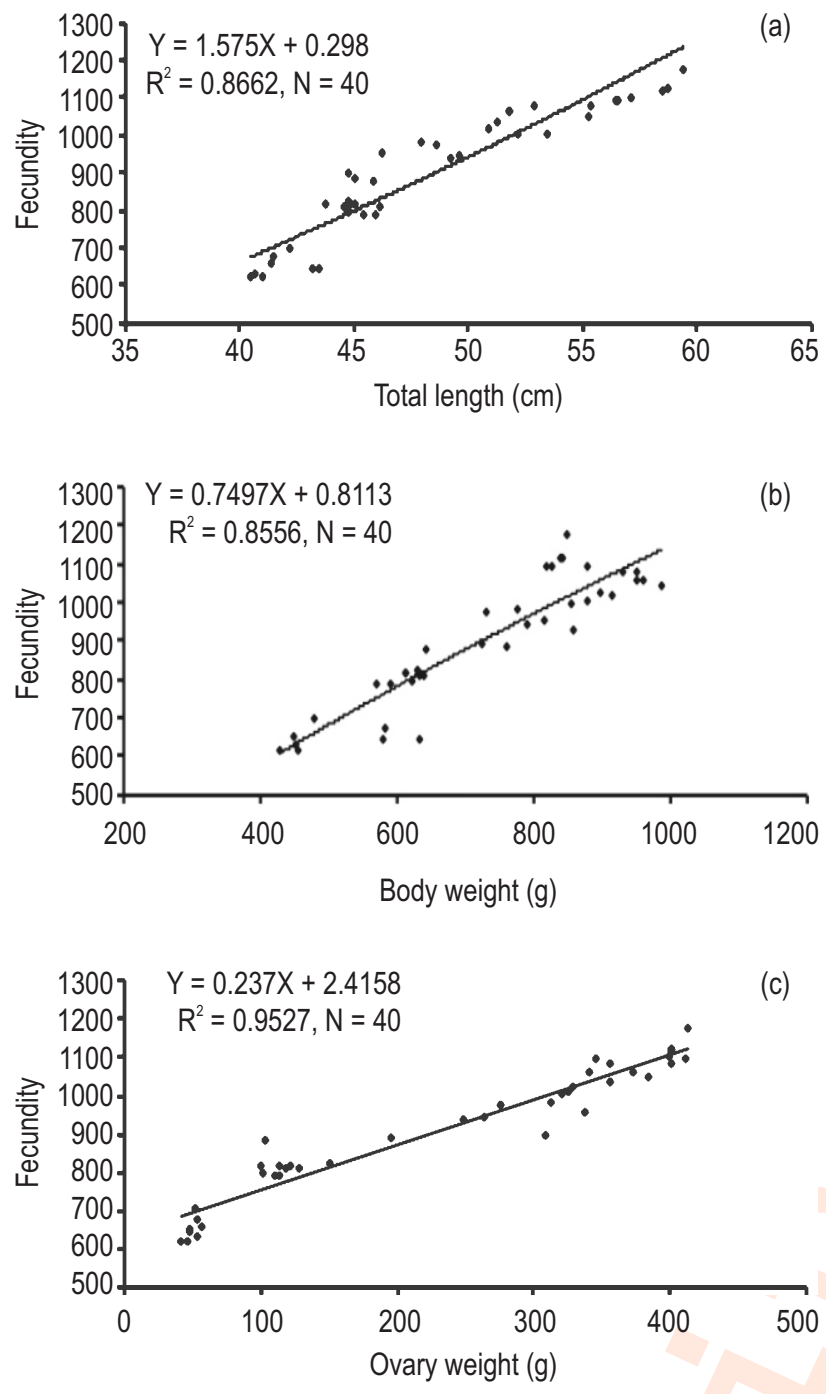

Fig. 12 : (a) Relationship between fecundity and total length; (b) relationship between fecundity and body weight; (c) relationship between fecundity and ovary weight of $P$. canius.

environment and season (Gupta and Gupta, 2006; Muchlisin et al., 2010; Gomes et al., 2011). Seasonal variation in the sex ratio can also occur after spawning activities when the female fish leaves the area in search of food (Offem et al., 2007). Knowledge of sex ratio in natural waters is crucial for artificial breeding so that appropriate numbers of males to females can mate (Amin et al., 2009).

Examining gonadal development has been stated as a convenient and inexpensive method of determining the spawning season of most fish species (Gomes and Araujo, 2004; Amin et al., 2009; Chelemal et al., 2009; Muchlisin et al., 2010; Shinkafi and Daneji, 2011). Five stages of gonadal development were found in both males and female $P$. canius based on the macroscopic appearance of their gonads. The gonadal developmental patterns from each sex were regular during various maturity stages (immature, maturing, mature, ripe and spent). The gonads were found to increase in size from immature to mature and were largest at the ripe stage, and thereafter declined after the gonads were spent. This development followed a similar pattern in most fishes (Gupta andand Gupta, 2006; Amin et al., 2009; Shinkafi and Daneji, 2011; Gupta and Benerjee, 2013). The increase in both weight and volume of gonads is a result of accumulation of trophic substances in the reproductive cells and increase in size of oocyte (Gupta and Gupta, 2006; Shinkafi and Daneji, 2011). Both gonadal maturation and GSI were employed in order to ascertain the spawning season of $P$. canius in the coastal waters of Port Dickson, Malaysia. It is clear from Fig. 6, 7 that both males and females were in a ripe condition for spawning from January to July. However, the percentage frequencies of mature and ripe gonads were higher (> 50\%) during February to April. The highest occurring frequencies of spent individuals were also recorded in May and June. These findings indicate that even though $P$. canius may have a prolonged spawning period extending from April to September, the peak spawning activity was between May and June for both sexes. These findings are further corroborated by the GSI values, which increased with fish maturation and were highest during the peak maturity. Afterwards, the GSI values suddenly declined when the fish became spent, thus indicating the breeding season. In this study, there was a gradual changing pattern of appearance of the testis and the ovary, as well as the GSI (Fig. 8). The highest GSI values were obtained in April, while the lowest were recorded in September in both males and females. This suggests a long period of spawning activity, which lasted from April to September, but the most active spawning occurred between May and June (Fig. 6, 7). Since this information has not been previously reported from the Malaysian coastal waters, this cannot be compared with other Malaysian populations. Nevertheless, Sinha (1981) suggested that the spawning period of $P$. canius was between February and August, with a peak between May and June off the coastal waters of India. Meanwhile, in waters off Bangladesh, it was suggested that $P$. canius spawned from April to July, with a peak in July (Khan et al. 2002; Ahmed and Haque, 2007). Therefore, further studies from Malaysia, as well as other sites, would help clarify this issue as well as identify any potential sitespecific differences.

The size at maturity of many fish species have been effectively assessed using the logistic curve (Kim, 2005; Kamrani et al., 2010; Olele, 2010). Based on this approach, the size at which $50 \%$ of male population matured was between $44-48 \mathrm{~cm}$ total length (mid length, $46 \mathrm{~cm}$ ), while for female population it ranged between $40-44 \mathrm{~cm}$ total length (mid length, $42 \mathrm{~cm}$ ). This suggests that the females attained sexual maturity earlier than the males. However, the values reported in this work were higher than $36.50 \mathrm{~cm}$ reported for $P$. canius from Bangladesh (Khan et al., 2002). It seems that the size at maturity of fish varies with 
locality. This result may further be explained by a number of different factors such as variability in habitat condition, environmental factors, body size and age of fish (Hart and Reynolds, 2008; Kamrani et al., 2010).

Fecundity is the total number of ova in the ovary of female fish and is the most common measure of reproductive potential in fishes. Generally, fecundity increases with increased size of female fish (Khan et al., 2002; Amin et al., 2009; Gupta and Gupta, 2006; Kamrani et al., 2010). In case of $P$. canius, the mean fecundity of 40 females was 943 eggs. The calculated maximum numbers of eggs of fish in this study were 1140 , and the minimum number of ova were 642 in females who ranged between 40 to 60 $\mathrm{cm}$ total length. The average fecundity per $1 \mathrm{~kg}$ of body weight was found to be 1226 eggs. This result also suggests that larger fish produce substantially more eggs than smaller fish. Nevertheless, the result is slightly lower than previous observation by Ahmed and Haque (2007).

Moreover, Khan et al. (2002) stated that fecundity was in the range of 1180 - 2250 eggs in female $P$. canius ranging from $36.5 \mathrm{~cm}$ to $69.2 \mathrm{~cm}$ total length. In this study, linear relationships between fecundity and total length, body weight and ovary weight were found, which is similar to findings by Khan et al. (2002). Besides, this relationship has been observed by many researchers; Araújo et al. (2012) in Neotropical fish, Crenicichla menezesi; Kamrani et al. (2010) in Swimming crab, Portunus pelagicus; Olele (2010) in Sarotherodon galilaeus; Hossain et al. (2010) in Gudusia chapra; Dupuis and Sutton (2011) in Humpback whitefish, Coregonus pidschian and González et al. (2012) in Sea louse Caligus rogercresseyi.

In conclusion, the knowledge on the reproductive biology of $P$. canius is useful for its conservation, successful culture and breeding program. A periodic closure during spawning season of this fish (from April to July) can afford better breeding opportunities for adult $P$. canius; this is considered to be a useful fishery management measure for this fish. Information on the size at maturity of fish facilitates predicting their harvestable size is of great advantage for the fisheries as well as aquaculture industry. Such information can be used as a guide for minimum permissible capture size, which is vital for conservation strategies of any fish species

\section{Acknowledgments}

This work was funded by Universiti Putra Malaysia (UPM) under a Research University Grant Scheme (RUGS) with a Grant no. 05-02-12-1703RU and LRGS/1/2019/UPM/1 (vote no. 5545102). Extended thanks to Mohd. Hazmadi Zakariya of the Aquaculture Department, UPM and Zul, the fisherman for their assistance in the field work. We would also like to thank Dr. Md. Aminur Rahman for his critical review and correction of this manuscript.

\section{References}

Adebiyi, F., S. Siraj, S. Harmin and A. Christianus: Plasma sex steroid hormonal profile and gonad histology during the annual reproductive cycle of river catfish Hemibagrus nemurus (Valenciennes, 1840) in captivity. Fish Physiol. Biochem., 39, 547557 (2013).

Ahmed, S.U. and A. Haque: Studies on the fishery biology and domestication of gang magur (Plotosus canius). BFRI Annual progress report. Bangladesh: Bangladesh Fish. Res. Inst., 76-79 (2007).

Ambak, M.A., M. Isa, Z. Zakaria and M.A. Ghaffar: Fishes of Malaysia. $1^{\text {st }}$ Edn., Malaysia: Pernebit Universiti Malaysia Terengganu (2010).

Amin, S.M.N., A. Arshad, J.S. Bujang, S.S. Siraj and S. Goddard: Reproductive biology of the sergestid shrimp Acetes indicus (Decapoda: Sergestidae) in coastal waters of Malacca, Peninsular Malaysia. Zoological Studies, 48, 753-760 (2009).

Araújo, A.S.D., W.S. do Nascimento, M.E. Yamamoto and S. Chellappa: Temporal dynamics of reproduction of the Neotropical fish, Crenicichla menezesi (Perciformes: Cichlidae). Sci. World J., 2012, Article ID 579051, 10 pages (2012).

Chelemal, M., S. Jamili and I. Sharifpour: Reproductive biology and histological studies in Abu Mullet, Liza abu in the water of the Khozestan province. J. Fish Aquat. Sci., 4, 1-11 (2009).

Cross, M.E., R.M. O'Riordan and S.C. Culloty: The reproductive biology of the exploited razor clam, Ensis siliqua, in the Irish Sea. Fish. Res., 150, 11-17 (2014).

De Bruin, G.H.P., B.C. Russell and A. Bogusch: FAO species identification field guide for fishery purposes. The marine fishery resources of Sri Lanka, p. 411 (1995).

Dupuis, A.W. and T.M. Sutton: Reproductive biology of female humpback whitefish Coregonus pidschian in the Chatanika River, Alaska. J. Appl. Ichthyol., 27, 1365-1370 (2011).

Ferraris, C.J.: Checklist of catfishes, recent and fossil (osteichthyes, siluriformes) and catalogue of siluriform primary type. USA, Magnolia Press (2007).

Ferriz, R.A., E.M. Fernández, C.A. Bentos and G.R. López: Reproductive biology of Pseudocorynopoma doriai (Pisces: Characidae) in the High Basin of the Samborombón River, province of Buenos Aires, Argentina. J. Appl. Ichthyol., 23, 226-230 (2007).

Gomes, I.D., F.G. Araujo, W. Uehara and A. Sales: Reproductive biology of the armoured catfish Loricariichthys castaneus (Castelnau, 1855) in Lajes reservoir, southeastern Brazil. J. Appl. Ichthyol., 27, 1322-1331 (2011).

Gomes, I.D. and F. Gerson Araújo: Reproductive biology of two marine catfishes (Siluriformes, Ariidae) in the Sepetiba Bay, Brazil. Rev. Biol. (Lisboa), 52, 143-156 (2004).

Gomiero, L.M. and F.M.S. Braga: Reproduction of species of the genus Cichla in a reservoir in southeastern Brazil. Braz. J. Biol., 64, 613624 (2004)..

Gomon, J.R.: Plotosidae. Western Indian Ocean fishing area 51 (Eds.: W. Fischer and G. Bianchi ), 3 (1984).

González, M.T., C. Molinet, B. Arenas, G. Asencioand and J. Carvajal: Fecundity of the sea louse Caligus rogercresseyi on its native host Eleginops maclovinus captured near salmon farms in southern Chile. Aquac. Res., 43, 853-860 (2012).

Gupta, S. and S. Banerjee: Studies on reproductive biology of Mystus tengara (Ham.-Buch., 1822), a freshwater catfish of West Bengal, 
India. Int. J. Aquat. Biol., 1, 175-184 (2013).

Gupta, S.K. and P.C. Gupta: General and Applied Ichthyology (Fish and

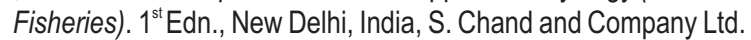
(2006).

Hart, P.J.B. and J.D. Reynolds: Handbook of fish biology and fisheries. Wiley. com, 2 (2008).

Hossain, M.Y., Z.F. Ahmed, A.B. Islam, S. Jasmine and J. Ohtomi: Gonadosomatic index based size at first sexual maturity and fecundity indices of the Indian River shad Gudusia chapra (Clupeidae) in the Ganges River (NW Bangladesh). J. Appl. Ichthyol., 26, 550-553 (2010).

IUCN: IUCN red list of threatened species. Accessed 15 August, 2017, from IUCN www.iucnredlist.org (2017).

IUCN Bangladesh: Red book of threatened fish of Bangladesh. The world conservation Union Appendix, 1, 61 (2000).

Kamrani, E.A.N., M. Sabiliand and M. Yahyavi: Stock Assessment and Reproductive Biology of the Blue Swimming Crab, Portunus pelagicus in Bandar Abbas Coastal Waters, Northern Persian Gulf. J. Pers. Gulf, 1, 11-22 (2010).

Khan, M.S.A., M.J. Alam, S. Rheman, S. Mondal and M.M. Rahman: Study on the fecundity and GSI of brackishwater cattish Plotosus canius (Hamilton-Buchanan). Online J. Biol. Sci., 2, 232-234 (2002).

Kim, S.: Population structure, growth, mortality, and size at sexual maturity of Palaemon gravieri (Decapoda: Caridea: Palaemonidae). J. Crustac. Biol., 25, 226-232 (2005).

Lawson, E.O.: Length-weight relationships and fecundity estimates in mudskipper, Periophthalmus papilio (Bloch and Schneider 1801) caught from the mangrove swamps of Lagos Lagoon, Nigeria. J. Fish. Aquat. Sci., 6, 264-271 (2011).

Liang, S.H., H.P. Wu and B.S. Shieh: Size structure, reproductive phenology, and sex ratio of an exotic armored catfish (Liposarcus multiradiatus) in the Kaoping River of southern Taiwan. Zool. Stud., 44, 252 (2005).

Mace, P.M.: Relationships between common biological reference points used as thresholds and targets of fisheries management strategies. Can. J. Fish. Aquat. Sci., 51, 110-122 (1994).

Mijkherjee, M., A. Praharaj and S. Das: Conservation of endangered fish stocks through artificial propagation and larval rearing technique in West Bengal, India. Aquac. Asia, 7, 8-11 (2002).
Mohsin, A.K.M. and M.A. Ambak: Marine fishes and fisheries of Malaysia and neighbouring countries. Universiti Pertanian Malaysia Press Serdang, 495 (1996).

Muchlisin, Z.A., M. Musman and M.N.S. Azizah: Spawning seasons of Rasbora tawarensis (Pisces: Cyprinidae) in Lake Laut Tawar, Aceh Province, Indonesia. Reprod. Biol. Endocrinol., 8, 49 (2010).

Murawski, S.A., P.J. Rago and E.A. Trippel: Impacts of demographic variation in spawning characteristics on reference points for fishery management. ICES J. Mar. Sci., 58, 1002-1014 (2001).

Nurnadia, A.A., A. Azrina and I. Amin: Proximate composition and energetic value of selected marine fish and shellfish from the West coast of Peninsular Malaysia. Int. Food. Res. J., 18, 137-148 (2011).

Offem, B.O., Y. Akegbejo-Samsons and I.T. Omoniyi: Biological assessment of Oreochromis niloticus (Pisces: Cichlidae; Linne, 1958) in a tropical floodplain river. Afr. J. Biotechnol., 6, 1966-1971 (2007).

Olele, N.F.: Reproductive Biology of Sarotherodon galilaeus (Artedi, 1757) in Onah Lake, Delta State, Nigeria. Res. J. Appl. Sci., 6, 1981-1987 (2010).

Riede, K.: Global register of migratory species: from global to regional scales. Final report for Research and Development-project, Federal agency for nature conservation, Bonn Germany, pp. 329 (2004).

Shinkafi, B.A. and A.I. Daneji: Morphology of the gonads of Synodontis eupterus (Boulenger) from River Rima, North-western Nigeria. Int. J. Zool. Res., 7, 382-392 (2011).

Sinha, M.: Length-weight relationship and relative condition factor of the canine catfish-eel Plotosus canius Hamilton. J. Mar. Biol. Ass. India, 23, 39-43 (1981).

Sinha, M.: Food preference studies of Plotosus canius Hamilton and its cultural suitability. Proceedings: Anim. Sci., 93, 437-443 (1984).

Sinha, M.: Age and growth of Plotosus canius Hamilton from HooghlyMaltah estuary, India. Indian J. Anim. Sci., 56, 116-126 (1986a).

Sinha, M.: Functional morphology, anatomy and histology of the digestive organs of the catfish Plotosus canius Hamilton. Proc. J. Anim. Sci., 95, 23-44 (1986b).

Wang, S.P., C.L. Sun and S.Z. Yeh: Sex ratios and sexual maturity of swordfish (Xiphias gladius L.) in the waters of Taiwan. Zool. Stud., 42, 529-539 (2003). 